\title{
Ubi Sumus? \\ Twenty Five Years Later ${ }^{1}$
}

\section{John B. Hattendorf}

Dans cet article sollicité qui complète le récent recensement de l'évolution de la Société canadienne pour la recherche nautique (CNRS) par Alec Douglas, John Hattendorf s'intéresse pour sa part à l'évolution de l'histoire maritime. Lors de la première parution de la présente revue, l'histoire maritime comprenait deux groupes distincts : l'histoire navale et tout le reste. Bien que les obstacles aient depuis tombés petit à petit, ce n'est qu'en 2008, par exemple, que l'histoire maritime s'est vue accorder une interprétation large comme domaine d'études légitime par la société American Historical Association. Pourtant, toutes les dimensions de l'activité humaine en mer sont liées à une activité comparable sur terre. Ces conséquences et ces rapports plus larges commencent à se répercuter dans la recherche et les écrits maritimes.

The silver jubilee of this journal, Northern Mariner/Le Marin du Nord, provides an opportunity to reflect once again on the state of our field and where we are now in relation to where we were twenty-five years ago in 1991. At that point, scholars in the field were just beginning to mobilize and to react to the dire situation we faced in North America. The establishments of this journal and its subsequent growth and development have been significant steps toward remedying that situation.

In the 1980s and early 1990s, maritime history in the English-speaking world was a fractured subject, divided into small groups of scholars who tended not to talk to one another. At the time, there was much doubt as to what maritime history was about. For a time "maritime" meant everything that was not "naval." The Englishlanguage word usage problem could be traced to Robert G. Albion's Naval \& Maritime History: An Annotated Bibliography, ${ }^{2}$ which dated from 1951 and was

\footnotetext{
${ }^{1}$ This article combines, updates, and extends two previous articles: "Maritime History Today" in Perspectives on History, 50:2 (February 2012), 34-36, and "Forum: [on the first 25 years of the International Journal of Maritime History] Naval History," International Journal of Maritime History, 25:1 (Feb 2014), 104-109.

2 Robert G. Albion, Naval \& Maritime History: An Annotated Bibliography. Fourth Edition Revised and Expanded. (Mystic, CT, 1972). Benjamin W. Labaree, A Supplement (1971-1986) to Robert G. Albion's Naval \& Maritime History: An Annotated Bibliography. Fourth Edition.
}

The Northern Mariner/Le marin du nord, XXVII, No. 1 (Jan. 2017), 1-13. 
continued through 1986. This work was a major contribution to the field in its time, but the title inadvertently suggested to some that naval and maritime were two different and separate fields. This was not Albion's personal view, as he had been working simultaneously in the opposite direction to see mankind's relationships with the seas and oceans of the world as a single broad theme. In that regard, as the first occupant of a an American academic chair in the field, he had urged Harvard University to name his new post the Gardiner Chair of Oceanic History and Affairs when he became its first occupant in 1948. The donor of the endowed chair had specified that the endowment "was to be used for the study and teaching of the geography and history of the sea and of the ships that sail on or above it, 'particularly as they have affected or may affect the security and progress of the United States in view of the mid-oceanic and insular position of North America relative to other lands." "This reflected the fact that the chair's namesake, William Howard Gardiner (1875-1952), had been president of the Navy League of the United States from 1928 to 1933 and his interests lay with naval international affairs. Albion, however, clearly saw that naval affairs were but a subspecialty within a much wider field. ${ }^{3}$

So, too, in 1973, the North American Society for Oceanic History (NASOH) was founded to try to develop that same idea. As Albion once explained, the person who had printed the first edition of his bibliography had taken it upon himself to "improve" the title without consulting Albion, thereby creating the issue. ${ }^{4}$ No doubt there were other factors involved, perhaps most notably the well-known tendency of some academics to carve out narrowly defined fields of specialty that they can defend and operate within, while trying to prevent intrusion by others. In 1994-95, surveys of the state of field showed very clearly that this was the case in Britain, Canada, and the United States, ${ }^{5}$ but not in the Netherlands ${ }^{6}$ and elsewhere. ${ }^{7}$

The resolution to the lingering issue in English language terminology took time to resolve. By the mid-1990s, the trends were favouring "maritime" over "oceanic"

(Mystic, CT: Mystic Seaport Museum Incorporated, 1988).

3 "In Memoriam: William Howard Gardiner, President of Navy League, 1928-1933," Now Hear

This [Newsletter of the Navy League of the United States], III:5 (June 1952), 1. For further information on Gardiner, see papers of William Howard Gardiner, Houghton Library, Harvard University, MS Am 2199.

${ }^{4}$ Author's recollection of a conversation with Robert G. Albion (1896-1983).

${ }^{5}$ Note in particular, N.A.M. Rodger, "Britain," where the issue is directly addressed, and the essays that implicitly reflect this: Gerald E. Panting and Lewis R. Fischer, "Maritime History in Canada: the Social and Economic Factors"; Mark Milner, "The Historiography of the Canadian Navy: The State of the Art"; Benjamin W. Labaree, "The State of American Maritime History in the 1990s"; Kenneth J. Hagan, "Mahan Plus One Hundred: The Current State of American Naval History," all in John B. Hattendorf, ed., Ubi Sumus; The State of Naval And Maritime History (Newport, RI: Naval War College Press, 1994), 41-57, 59-77, 79-92, 363-378, 379-405.

${ }^{6}$ Jaap R. Bruijn, "The Netherlands," ibid, 227-243.

${ }^{7}$ Frank Broeze, ed., Maritime History at the Crossroads: A Critical Review of Recent Historiography. Research in Maritime History, 9. (St John's, Newfoundland, 1995). 
as the overarching term, but this was not resolved fully until 2007 and 2008, although NASOH continues to retain "oceanic" in its name as an historical curiosity. The process of resolution began in 1985 when a group of American academics felt that the study of maritime history was close to extinction and called for a national effort to revitalize and to coordinate new efforts and new approaches to the field. The Council of American Maritime Museums was the first to answer that call when it established a committee on higher education to examine the issue. In 1989, the committee reported that while museums such as Independence Seaport Museum in Philadelphia, the Mariners' Museum in Virginia, Mystic Seaport, New Bedford Whaling Museum, Peabody-Essex Museum in Salem, San Diego Maritime Museum, San Francisco Maritime National Historical Park, and South Street Seaport among many others, were actively supporting maritime history, public education in the field was disadvantaged and that there was a general lack of awareness of the field within the academic community. At that time, the museums noted that there was no place in academia to send their staff members for education in either maritime or naval history. Except for an occasional course on a university campus, such as Gaddis Smith's lectures on maritime history at Yale, the only other alternative was the Frank C. Munson Institute of American Maritime Studies, which had been founded at Mystic Seaport by Harvard's Robert G. Albion and Edouard Stackpole in 1955, as a summer course with graduate level credit. It has continued for more than sixty years to educate many of the leaders in the maritime field in academia, museums, and archives. ${ }^{8}$

A further step was taken in 1993, when Professor Paul M. Kennedy's International Security Program at Yale University and the Naval War College sponsored a joint conference at New Haven to compare and to contrast the state of naval and maritime history in different countries and in different languages. The proceedings of this conference were published by the Naval War College under the title Ubi Sumus? ${ }^{9}$ and this joint conference was followed over the next several years by two others on naval history, one looking at ways to improve approaches to that sub-specialty within maritime history ${ }^{10}$ and another as a case study to consider naval issues over time in one specific ocean basin, in that case the Mediterranean. ${ }^{11}$

These initial efforts were complemented in 1995 by a volume of essays organized by the eminent Dutch-born, Australian scholar, Frank Broeze, which offered a critical assessment of recent historiography. ${ }^{12}$ It all helped move the field

\footnotetext{
${ }^{8}$ Benjamin W. Labaree, “ The Frank C. Munson Institute of American Maritime Studies," American Neptune, XLV (1985), 41-45.

9 John B. Hattendorf, ed., Ubi Sumus? The State of Naval and Maritime History.

10 John B. Hattendorf, ed., Doing Naval History: Essays toward Improvement. (Newport: Naval War College Press, 1995).

11 John B. Hattendorf, ed., Naval Strategy and Policy in the Mediterranean: Past, Present, and Future. (London: Frank Cass, 2000).

${ }^{12}$ Frank Broeze, ed., Maritime History at the Crossroads: A Critical Review of Recent Historiography.
} 
past its perceived antiquarian pursuits. Since then, leaders in the field have been seeking to connect better with the broader academic historical profession in terms of approaches and arguments. Beyond the dichotomy that existed in the Englishspeaking world between maritime and naval, there were additional subdivisions of subfields. Most notably on the naval side was the focus on a single national navy to the exclusion of others, as well as a division between those who studied naval operations and those who looked at naval administration. On a personal note, when I first took up the E.J. King Chair of Maritime History at the US Naval War College in 1984, one person told me that the word "maritime" in the title was intended only to extend the position's scope from the history of the US Navy to the US Marine Corps. Among others working in the field, Frank Broeze was certainly correct when, as early as $1989,{ }^{13}$ he had called for the need to re-conceptualize the subject in a much broader way that would do away with such narrow dichotomies and to begin to bring maritime history into the mainstream of general historical studies. As Broeze wrote in his 1995 compilation, "the first step must be to agree that that its purpose is the study of all aspects of the interaction between mankind and the sea. This specifically includes naval history, although that in itself remains a legitimate specialization, just as there are other such specializations, such as maritime economic history, maritime social and cultural history, and the history of maritime leisure and sporting pursuits." "As an emblem of the field's youth in this transition, the American Historical Association recognized maritime history only as recently as 2008 among its taxonomy of specializations that members may use to identify their interests. In choosing the word "maritime" to identify specialists in the field, the Association explicitly recognized the term as the overarching description for the field that included the range of subspecialties that ranged from naval to economic, exploration and social history to nautical science, and technology to art and literature. Significantly, the twenty-second Congress of the Comité International des Sciences Historique / International Commission of the Historical Sciences included, for the first time, a section on maritime history in its main program, when it met in Jinan, China, in August 2015. In previous congresses, maritime history was dealt with in special sessions sponsored by affiliated organizations. The congress at Jinan had a roundtable discussion entitled "Closing the Blue Hole" that discussed the challenges of international maritime historical research as a discipline based on the observation of a disconnect between historical sciences at large and the small group of maritime historians interested in the marine realm. Organized by Ingo Heidbrink, who gave the main paper, Lewis Fischer, Feng Shei, Malcolm Tull and Stig Tenold provided responses. The whole set of contributions will be published in a forthcoming issue of the International Journal of Maritime History.

\footnotetext{
13 Frank Broeze, "From the periphery to the Mainstream: The Challenge of Australia's Maritime History", The Great Circle XI (1989), 1-13.

${ }^{14}$ Broeze, "Introduction", to Maritime History at the Crossroads, xix.
} 
The modern field of maritime history includes some areas of narrower specialization that have a long history of their own. The oldest subject area within the English-language scholarly tradition of maritime history is the subject of exploration at sea, a topic that stretches back even before the works of Richard Hakluyt and the great compilation of early voyage accounts that he made during the Elizabethan age, particularly The Principal Navigations, Voyages, Traffiques, and Discoveries of the English Nation (1598-1600). The late nineteenth century Regius Professor of History at Oxford University, James Anthony Froude, called this work "The prose epic of the English nation." 15 The history of nautical science, navigation, and cartography, grew out of efforts to elucidate the history of the early maritime voyages and to chart the historical path toward modern approaches to navigation. The second oldest is maritime economic history, which may be said to trace its origins in English to the literature surrounding the establishment of the chartered trading companies, the rise of the first British empire, and fishing rivalries in works such as Hakluyt's manuscript "Discourse of Western Planting" (1587), Tobias Gentleman, England's Way to Win Wealth, and to Employ Ships and Mariners (1614), and Thomas Mun, England's Treasure by Foreign Trade (1664). The third -oldest sub-discipline in the English language tradition is naval history, which originated in Great Britain with Josiah Burchett's A Complete History of the Most Remarkable Transactions at Sea. (1720). ${ }^{16}$

Over time, the key traditional themes for maritime history developed around three separate and isolated aspects: the history of maritime exploration, naval warfare, and economic affairs, including shipbuilding, overseas trade, and commercial fishing. In these areas, North American scholars such as Robert G. Albion, William Bell Clark, Gerald Graham, Clarence H. Haring, John G. B. Hutchins, John H. Kemble, Benjamin W. Labaree, Arthur Marder, Samuel Eliot Morison, J. H. Parry, Donald M. Schurman, and Lawrence C. Wroth, published some of the classic works in the field. Traditional maritime history had little to say about social and cultural matters which appeared mainly in biographies of leading figures in industry, exploration, and naval affairs. In this, the biographies of naval commanders dominated. The emphasis on a national perspective on naval warfare and on isolated aspects of economic history contributed to maritime history's marginalization in academia during the mid-twentieth century as the broader historical discipline turned during the 1960s and 1970s toward other broader approaches in social and cultural history. While the subject remained popular in the public history sphere at museums and important in the context of professional

\footnotetext{
15 J. A. Froude, "England's Forgotten Worthies," Westminster Review (July 1852); reprinted in Short Studies on Great Subjects. (London, 1867), vol. 1.

${ }^{16}$ This and the following paragraphs are a restatement and summation of the author's introduction to John B. Hattendorf, editor in chief, The Oxford Encyclopedia of Maritime History (Oxford and New York: Oxford University Press, 2008), xvii-xix.
} 
education for the merchant marine, navy, and coast guard, for decades, maritime scholarship failed to follow these and other shifts in academia. ${ }^{17}$

\section{Maritime History Today}

More recent initiatives have sought to move beyond these traditional approaches in an effort to identify maritime history as a broad, interdisciplinary theme in global history, moving beyond the limitations of national perspectives. In this, the term "maritime history" has come to be recognized as an overarching term that describes a broad-ranging analytical understanding of mankind's multiple relationships with the oceans, seas, and waterways of the world. Put another way, maritime history is a multidimensional humanistic study of human activities, experiences, interactions, and reactions with the vast water-covered regions of our globe. A student who pursues maritime history may approach it from a variety of vantage points, including science and technology, industry, economics, trade and business, art, literature, military and naval affairs, international relations, and comparative studies in imperial and colonial affairs, communications and transportation, intercultural relations and exchange, law, institutional and organizational development, or the exploitation and conservation of natural maritime resources. An additional range of issues include social relations and labour, sports, and recreation. In virtually all of these areas, one can investigate both relations at sea as well as sea-land relationships. What unites the field across this range of interrelated vantage points is their engagement with similar, complementary and comparative experiences, social relations, and the changing uses of science and technology. Under the overarching label of maritime history, each of these subspecialties is closely related to a specific range of academic approaches. The maritime economic historian has fundamental ties to the academic fields of economic and business history; the student of the history of maritime technology can not work without the ties to engineering and to naval architecture; the historian of naval operations has connections to the diplomatic, military, and international history fields; the historian of navigation within the discipline of the history of science and technology; the student of maritime art or maritime literature has connections to the wider fields of art history or literature; the historian of exploration has ties to the history of imperial expansion and global interaction; the maritime environmental historian depends on the connections to the natural sciences. Each of these connections to already established academic disciplines and specialized fields of interest helps to define those particular subspecialties, but they are connected to one another through having the maritime element in common. It is this maritime element, with its cross connections and relations across the various subspecialties, that becomes that

\footnotetext{
${ }^{17}$ A forum on the current state of naval history appears in Andrew Lambert, John Beeler, Barry Strauss, and John B. Hattendorf, "The Neglected Field of Naval History? A Forum" Historically Speaking, 11:4 (September 2010), 9-19.
} 
revealing and important extension to broad aspects of national and international events ashore.

In the area of European naval history, two scholars in particular have produced important studies that provide models for future work in naval history: N.A.M. Rodger of Oxford University has completed two of the three volumes in his magisterial naval history of Britain, while the late Jan Glete of Stockholm University published several important comparative studies that examine the relationships of navies to the state-building process in early modern Europe. Much of the "new maritime history" has focussed on social and cultural history. Work by Margaret Creighton, Cheryl Fury, Paul Gilje, Jesse Lemisch, Christopher Magra, Lisa Norling, Marcus Rediker, Billy G. Smith, and Daniel Vickers have all helped to energize the field. Among them, Daniel Vickers ${ }^{18}$ Margaret Creighton, and Lisa Norling, ${ }^{19}$ have specifically pointed out the differences between old and new approaches. In this, the renewed emphasis on people, rather than ships or battles, has connected life at sea with its interrelationships to life on land. The new Atlantic and global approaches to the past have also helped to re-energize maritime history, most particularly through the studies of the Atlantic world by Bernard Bailyn, David Armitage, and Jack P. Greene. The new Atlantic and global histories focus on transoceanic connections and comparisons that emerged over time as a result of the movement of peoples, goods, and ideas that are central to this integrative process across the globe involving oceans, ships, and sailors. Scholars such as Daniel Finamore, Michael J. Jarvis, Peter Linebaugh, Christopher M. Magra, Marcus Rediker and have published work that has contributed to the further development of this approach. In 2010 and 2011, the Mariner's Mirror, Research in Maritime History, and The International Journal of Maritime History, published the perspectives of leading scholars as Lewis R. Fischer, Maria Fusario, Alan James, Roger Knight, Andrew Lambert, and Amélia Polónia on developments in the field. ${ }^{20}$

\section{Organizations and Journals}

Researchers and academics in many countries with a strong maritime element in their national experience have had long-established scholarly societies that publish

\footnotetext{
18 Daniel Vickers, “Beyond Jack Tar," William and Mary Quarterly, $3^{\text {rd }}$ Series. 50:2 (April 1993), 418-24.

19 Margaret Creighton and Lisa Norling, Iron Men, Wooden Women: Gender and Seafaring in the Atlantic World, 1700-1920. (Baltimore: The Johns Hopkins University Press, 1996), vi-xi.

${ }^{20}$ See in particular, Maria Fusario and Amélia Polónia, eds., Maritime History as Global History. Research in Maritime History, 43. (St. John's, Newfoundland, 2010) and Lewis R. Fisher, "Are we in Danger of being Left with our Journals and Not Much else: The future of maritime history?" Mariner's Mirror. 97:1 (2011), 366-381. For naval history, See Alan James, "Raising the Profile of Naval History," Andrew Lambert, "The Construction of Naval History, 1815-1914," and Roger Knight, "Changing the Agenda: the New Naval History of the British sailing navy," Mariners Mirror. 97:1 (2011), 193-242.
} 
peer-reviewed journals in the field. The most widely known among them are the Nederlandse Vereniging voor Zeegeschiedenis in The Netherlands, which publishes Tijdschrift voor Zeegeschiedenis, ${ }^{21}$ the Sjöhistoriska Samfundet in Sweden, which publishes Forum Navale, ${ }^{22}$ and the Société Française d'Histoire Maritime in France, which publishes three times a year La Chronique d'Histoire Maritime and annually the Revue d'histoire maritime. ${ }^{23}$ In addition, a number of national maritime museums that sponsor active research programs publish peer-reviewed academic yearbooks that contribute substantially to the scholarly discussion in the field. Particularly well known among these yearbooks are the Deutsches Schiffahrtsarchiv, ${ }^{24}$ published by the Deutsches Schiffahrtsmuseum as a German national museum and federal research center, the Arbok ${ }^{25}$ of the Norsk Maritimt Museum in Oslo, and a number other yearbooks published by more specialized museums. In the English-speaking world, the most prominent scholarly organizations are the century-old Society for Nautical Research in the United Kingdom, publisher of The Mariner's Mirror, ${ }^{26}$ and the Australian Association for Maritime History, which publishes Great Circle. ${ }^{27}$ With the untimely demise in 2002 of the American Neptune, which up to that time had been the premier journal for the field of maritime history in North America and published by the Peabody Essex Museum in Salem, Massachusetts since 1941, the field was suddenly left bereft of a scholarly journal. After a long period of negotiation in the hope that the American Neptune could be revived or moved to another organization, the Canadian Nautical Research Society ${ }^{28}$ and the North American Society for Oceanic History agreed to, join forces in 2006 to publish jointly the Northern Mariner/Le Marin $\mathrm{du} \mathrm{Nord}^{29}{ }^{29}$ circulating it as a perquisite of membership within each organization.

While most of the journals mentioned above have begun to widen their perspective beyond their traditional national outlook, some more recently established organizations and journals have been established to take a broader global perspective from the outset. The lead in this was taken by the International Maritime Economic History Association with its International Journal of Maritime History, established in 1989, with its series of monographs, Research in Maritime History. ${ }^{30}$ Initially, the International Journal of Maritime History focussed only on the subfield of its sponsors, economic history. Over the span of a single generation of

\footnotetext{
21 See http://www.zeegeschiedenis.nl/

22 See http://www.sjohistoriskasamfundet.se/

23 See http://www.sfhm.asso.fr/

${ }^{24}$ See http://www.dsm.museum/service/publikationen/deutsches-schiffahrtsarchiv-dsa.372.de.html

${ }_{25}$ See http://www.marmuseum.no/no/forskning/egne_publikasjoner/\%C3\%85rboken.d25-

SwJrUX1.ips

${ }^{26}$ See http://www.snr.org.uk/

27 See http://www.aamh.asn.au/

28 See http://www.cnrs-scrn.org/

29 See http://www.cnrs-scrn.org/northern mariner/index.html

${ }^{30}$ See http://www.mun.ca/mhp/imeha.htm
} 
editors and readers, it broadened its focus to the entire range of maritime history, and in 2016, the organization changed its name to International Maritime History Association to reflect the change of scope. With the name change, the journal moved from its original base of operations at the Memorial University of Newfoundland, where the valuable Maritime History Archive is located, ${ }^{31}$ to the Maritime Historical Studies Centre at the University of Hull in England. ${ }^{32}$

More recently, e-journals have emerged founded on wider perspectives. These include the Journal for Maritime Research published by the National Maritime Museum, Greenwich, now also published in hard copy format, ${ }^{33}$ Coriolis: Interdisciplinary Journal of Maritime Studies, produced on-line by Mystic Seaport Museum; ${ }^{34}$ and another e-journal for one of the subspecialties, the International Journal of Naval History: A Global Forum for Naval Historical Scholarship. ${ }^{35}$ Among maritime history journals, the European Science Foundation's European Reference List for the Humanities has recognized both the International Journal of Maritime History and The Mariner's Mirror as Class One journals, their highest level for scholarly journals.

While there is a relatively wide range of opportunities for publishing articlelength research, it is much harder to find publishers in the United States for booklength monographs. Until this year, the University Press of Florida was the leading publisher in the field with its fine series on "New Perspectives on Maritime History and Nautical Archaeology," edited by James C. Bradford and Gene A. Smith, and a planned series of NASOH handbooks that could be used for teaching maritime history. Early in 2011, the University Press of Florida abruptly cancelled these series and was not revived by another publisher. The US Naval Institute Press ${ }^{36}$ has now taken its place for scholarly works on naval affairs in the United States, while the Boydell Press has become the leading publisher in the United Kingdom for maritime history. ${ }^{37}$

\section{Broad Perspectives on the Field}

The publication of The Oxford Encyclopedia of Maritime History in 2007 with 400 contributors from fifty different countries marked the appearance of the first attempt

\footnotetext{
31 https://www.mun.ca/mha/

32 http://www2.hull.ac.uk/fass/maritimehistory.aspx

33 From May 2011, now just appearing in both electronic and print versions distributed by Routledge as part of the Taylor \& Francis Group, the new JMR website is now available at www.informaworld.com/rmar, with further information available at www.tandf.co.uk/journals/rmar

34 See http://ijms.nmdl.org/

35 See http://www.ijnhonline.org/

36 See http://www.usni.org/store/books

37 See https://boydellandbrewer.com/catalogsearch/result/index/?q=maritime\&subject=1064
} 
to organize a global academic reference work for the field. As reviewers pointed out, its strengths and weaknesses reflected the state of the field at the time of publication.

A few years later, in June 2010 issue of The International Journal for Maritime History contained several important reflective articles written on a broad scale. Chief among them were David M. Williams' "Humankind and the Sea: The Changing Relationship since the Mid-Eighteenth Century" and Lincoln Paine's "Beyond the Dead White Whales: Literature of the Sea and Maritime History." Both reflect the new beginnings of the growing number of perspectives on the subject with Williams showing the gradual shift from an emphasis on economic issues to wider social issues as the relationship with the sea became a global one, and the more recent addition of environmental and ecological issues, during the last half century. At the same, Paine argued for the need to go beyond the usual list of Anglophone writers. As he pointed out, the purpose of putting to sea is to establish wider connections and the parochial canon of Anglo-American literature has failed to do this across either space or time.

Lincoln Paine's magnificent and beautifully written overview of this complicated field, The Sea and Civilization: A Maritime History of the World ${ }^{38}$ was the first attempt of a single author to range over the full history of global maritime history from ancient times onward, using modern perspectives that include a wide range of insights from different historical disciplines including underwater archeology.

In France, a major research project, which the Océanides Association has been working on since 2011, will produce in both French and English in early 2017, its huge four-volume survey entitled The Sea in History. ${ }^{39}$ Created under the leadership of its editor in chief, Christian Buchet of the Catholic University of Paris, it includes the work of some 300 contributors from five continents, including North Americans, who present the topic chronologically and thematically. The volume on The Ancient World is edited by Philip de Souza and Pascal Arnaud; The Medieval World, by Michel Balard; The Early Modern World, by Buchet and Gérard Le Bouëdec, and The Modern World, by N.A.M. Rodger. In each volume, the contributors assess to what degree the sea has been important in history, taking up the topic in a total of some 250 essays that, attuned to their broad period, examine economic development, warfare, the building of cities, empires, and nations, social aspects of sailors and maritime communities, and nearly every aspect conceivable. These volumes promise to be a huge contribution to the field of lasting quality.

\footnotetext{
${ }^{38}$ Lincoln Paine, The Sea and Civilization: A Maritime History of the World. (New York: Alfred A. Knopf, 2013; paperback, New York: Vantage, 2015).

${ }^{39}$ Christian Buchet, editor in chief, The Sea in History. Four volumes. (Woodbridge Surry and Rochester, NY: The Boydell Press, forthcoming in February 2017).
} 


\section{The State of Maritime History in the United States}

In all subspecialties of maritime history, one would expect that transnational and multi-disciplinary approaches to understanding the past will open up avenues for research into the ways in which mankind's relationship with the sea has had an impact on human history, but this has not always been the case. The American maritime experience is a complex one with its diversity of coastlines ranging from the Great Lakes, Atlantic, Pacific, Caribbean, to the Arctic. Some years ago at a NASOH conference, Ingo Heidbrink, professor of maritime history at Old Dominion and secretary-general of the International Commission of Maritime History (since 2016 amalgamated with the International Maritime Economic History Association into the International Maritime History Association), pointed out that the current state of maritime historical research in the US shows a number of similarities with situations in other nations, but also some important differences. Most notable of the latter is the relatively low level of international perspective in the work of American scholars. While many of the more active national commissions of maritime history are regularly represented at the major international conferences on maritime history, for example the conferences organized by the International Maritime Economic History Association (IMEHA), the North Atlantic Fisheries History Association (NAFHA), or the International Commission of Maritime History (ICMH), only a very small number of US-based maritime historians have been represented at these meetings during the last decade. In particular, younger US-based maritime historians have rarely participated in these international conferences. An explanation for this might simply be that maritime history in the US deals with such a large array of domestic topics that many colleagues do not feel the need to take on the burden of international comparative historical analysis. Yet, as Heidbrink suggested, although there are more maritime historians in the United States than in any other country, to other historians around the globe they appear to have become more of an obstacle to than a catalyst for international cooperation. This difference between maritime history as practised outside the United States and that within has also meant that many leading US maritime historians are, to a certain degree, strangers to their respective international counterparts.

In contrast, an important similarity between US and foreign maritime historians is their tendency to identify with their subspecialty rather than with the broader field of maritime history. While a significant number of historians see themselves as maritime historians, many more scholars engaged in maritime history-related research do not yet come to use the term maritime history to describe their research area. For example, colleagues dealing with the history of fisheries tend to avoid calling themselves maritime historian and use terms such as fisheries history or maritime environmental history that describe their areas of sub-specialization. Some naval historians do the same, as do maritime economic historians and others. Of course, these terms are more precise than maritime history and they are more compatible with the needs of the academic hierarchy, which by and large does not 
yet acknowledge the field of maritime history. While this is understandable, at the same time, this predilection supports the tendency to compartmentalize an already small field of maritime history into such narrow interest groups that the larger maritime picture is easily lost and historians risk overlooking the broad interconnections and broader perceptions that other disciplines are bringing to the maritime field.

In the United States, while there has long been a widespread interest in maritime history in the museum and archival fields, the National Endowment for the Humanities (NEH) has been concerned about the lack of teachers for maritime historical studies in American universities, particularly in the years between 1982 and 2001, when the Gardiner Professorship in Oceanic History and Affairs at Harvard was in abeyance. Since 1992, the NEH has sponsored five summer institutes in maritime history for college and university teachers to try to promote undergraduate teaching in this area. Over this quarter century, two summer institutes on maritime history were held at the John Carter Brown Library at Brown University $^{40}$ and five at the Frank C. Munson Institute of American Maritime History at Mystic Seaport. ${ }^{41} \mathrm{NEH}$ support in this effort has been a highly significant and continuing assistance for the field of maritime history. In another initiative supported by the National Maritime Historical Society, Joshua M. Smith has produced a two-volume paperback set, entitled Voyages: Documents in American Maritime History, which he designed for use in teaching undergraduate course. ${ }^{42}$ While the subject is not yet widely taught, thanks to the initiatives of the National Endowment for the Humanities individual scholars and teachers are appearing more frequently on campuses across the country. Complementing the $\mathrm{NEH}$ effort is the distinguished summer graduate-level program held annually at the Munson Institute, In addition, East Carolina University and Texas A \& $\mathrm{M}$ have a well-established programs in maritime history and underwater archaeology. On the west coast, San Diego, the University of Washington, and other academic institutions are developing maritime environmental history. The Great Lakes Center for Maritime Studies, established in 1997, is located at Western Michigan University. With the arrival at Old Dominion University of Ingo Heidbrink from Germany, there is strong hope for further developments with the maritime resources in archives, museums, and libraries available throughout the Chesapeake Bay region. Significantly, Heidbrink also brought with him the secretariat of the International Commission for Maritime History today the secretariat of the International Maritime History Association. This,

\footnotetext{
40 These produced two volumes on the period 1540-1815: John B. Hattendorf, ed., Maritime History. (Malabar, FL: Krieger Publishing, 1996-97).

${ }^{41}$ The first of these produced an illustrated textbook for teaching: Benjamin Labaree, et al, America and the Sea: A Maritime History. (Mystic CT: Mystic Seaport Museum, 1998).

${ }^{42}$ Joshua M. Smith and the National Maritime Historical Society, eds., Voyages: Documents in American Maritime History, vol. 1, "The Age of Sail, 1492-1865"; vol. 2, "The Age of Engines, 1865-present," (Gainesville: University Press of Florida, 2009).
} 
along with NASOH's role within the International Commission on Maritime History and its successor, should be a major assistance in helping American scholars connect with the wider world of international scholarship in the field of maritime history.

Forthcoming conferences of NASOH and CNRS as well as those around the globe within the next few years will provide ideal opportunities for American maritime historians to set their research within broader analytical and international perspectives. Currently, the largest and most diverse of the conferences are the quadrennial International Maritime History Association conference, the next of which will take place in 2020 in Portugal, and the biennial McMullen Naval History Symposium at the US Naval Academy at Annapolis, the next which takes place on 14-15 September 2017.

It takes time for new approaches to develop with any academic field, but a transition in approach and gradual intellectual broadening of maritime history is clearly in progress, both in the United States, Canada, and around the world. While North Americans, by and large, appear at the moment to be somewhat behind many of their international colleagues in these academic developments, there is clear evidence of improvement. The basic trends taking place clearly show that scholars within the various subspecialties of maritime history, as well as those who have previously confined themselves to a single national approach to maritime history, are clearly beginning to widen their intellectual perspectives, use a wider range of languages and archives in their work, and consider the fuller implications of their research. 